\title{
"In Vitro" Antibacterial Activity of the Hidroalcoholic Extract of the Schinus terebinthifolius Raddi Barks
}

\author{
Erica Renata Nogueira Sá1, Cássio Ilan Soares Medeiros ${ }^{1 *}$, \\ Juliana Raquel de Morais Santos Oliveira1, Antonio José de Jesus Evangelista², \\ Maria Iranilda Silva Magalhães 3 , Geraldo Gonçalves de Almeida Filho4, \\ Andréa Maria Rolim da Paz ${ }^{4}$, Hilzeth de Luna Freire Pessôa ${ }^{5}$

\footnotetext{
${ }^{1}$ Department of Microbiology Research, Integrated College of Patos, Patos, Brazil

${ }^{2}$ Department of Medical Sciences, Federal University of Ceará, Ceará, Brazil

${ }^{3}$ Department of Health Sciences, Cruzeiro of Sul University, São Paulo, Brazil

${ }^{4}$ Department of Pharmaceutical Technology, Federal University of Paraíba, João Pessoa, Brazil

${ }^{5}$ Department of Cell and Molecular Biology, Federal University of Paraíba, João Pessoa, Brazil

Email: ${ }^{*}$ cassioism@hotmail.com
}

Received 2 June 2014; revised 5 July 2014; accepted 8 August 2014

Copyright (C) 2014 by authors and Scientific Research Publishing Inc.

This work is licensed under the Creative Commons Attribution International License (CC BY).

http://creativecommons.org/licenses/by/4.0/

(c) (i) Open Access

\begin{abstract}
The Schinus terebinthifolius Raddi is a native plant of South America popularly known in Brazil as aroeira. It is a medium-sized plant, which demonstrates a high adaptive potential in various environments, besides having various medicinal properties such as anti-inflammatory and antidiarrheal. Bacterial susceptibility tests were carried out and the minimal inhibitory concentration (MIC) was obtained. The results were interpreted based on the conventionally microbiological protocols and data from the CLSI. For the microbiological tests, microorganisms obtained from the American Type Culture Collection (ATCC), specifically, (Pseudomonas aeruginosa, Staphylococcus aureus and Encherichia coli) were used. Of the tested bacterial strains, only the Staphylococcus aureus 6538 presented susceptibility to the aroeira's hydroalcoholic extract, forming zones of inhibition of $8.0 \mathrm{~mm}$ of diameter up to the MIC of $35.3 \mathrm{mg} / \mathrm{mL}$, while the other tested strains showed to be resistant in all the concentrations of hydroalcoholic extract of the Schinus terebinthifolius Raddi bark. Our aim is to analyze the "in vitro" antibacterial potential of the $70 \%$ hydroalcoholic extract of the Schinus terebinthifolius Raddi.
\end{abstract}

\section{Keywords}

Aroeira, Antibacterial Activity, Schinus terebinthifolius Raddi, Hydroalcoholic Extract

${ }^{*}$ Corresponding author. 


\section{Introduction}

Schinus terebinthifolius Raddi is a plant popularly known as aroeira. This plant belongs to the Anacardiaceae family, which contains 70 genus and more than 600 species of trees and bushes [1] [2]. It is native of South America, where it stands out in countries such as Paraguay, Peru, Argentina and Brazil. But it may also be found in semitropical and tropical regions of the United States, Africa and even in Oceania [3] [4]. In Brazil due to the great variety and diversity of the vegetation, it is easily found; as it is present from the state of Pernambuco to the state of Rio Grande do Sul [5].

The aroeira is a medium-sized plant, demonstrating a high adaptive potential in various environments [6]-[8]. This plant has various medicinal properties such as: antidiarrheal, astringent, anti-inflammatory, febrifuge and anti-allergic [1] [9] [10]. It is popularly used as a healing agent, in inflammations and ulcers, against toothache, hematomas, contusions and hemoptysis [7] [10] [11]. Furthermore, the Schinus terebinthifolius is not only utilized for medicinal use, but also for dental treatments and as a base for some medicines [12]-[14].

Due to the evolution and dissemination of the antimicrobial resistance owing to the excessive and indiscriminate use of antibiotic agents in the health sector, the use of natural bioactive agents seems promising to us [15] [16]. The S. aureus is among the most frequent nosocomial pathogens, as the resistance to multiple drugs is common and contributes to the difficulty in the treatment of infections [17]-[19].

For economic reasons the large pharmaceutical industries have abandoned the search for new antimicrobial compounds. But in the past this was the main objective for the development of antimicrobial agents. However, the search for new alternatives for the antibacterial therapy has been focused in the search for new antibiotics that act on new molecular targets of the pathogens and are not affected by the resistance mechanisms, as well as in the search for inhibitors of these resistance mechanisms [20]. In light of this context our aim is the analysis of the in vitro antibacterial activity of the hydroalcoholic extracts of Schinus terebinthifolius Raddi.

\section{Materials and Methods}

\subsection{Harvesting, Drying and Elaboration of the Crude Extract of the Aroeira}

The vegetal natural product, (Schinus terebinthifolius Raddi barks) were appropriately harvested in the woods of a region of the northeast of Brazil. The barks were processed away from the light at a temperature of $60^{\circ} \mathrm{C}$ for the removal of its humidity [21] [22]. After the drying the vegetal material was ground and stored in tubes, where were added $15 \mathrm{~mL}$ of $70 \%$ alcohol for the elaboration of the hydroalcoholic solution and posteriorly submitted to the TS-2000 VDRL SHAKER, for 120 min. Then the product was vaporized in the Rotavapor Fisatom 801, until the total vaporization and attainment of the crude extract. The $170 \mathrm{mg}$ of the crude extract were diluted in $430 \mu \mathrm{L}$ of $0.9 \%$ physiological solution to obtain an approximate concentration of $283 \mathrm{mg} / \mathrm{mL}$.

\subsection{Preparation and Use of the Bacterial Strains}

The in vitro antibacterial properties of the $70 \%$ hydroalcoholic extract of Shinus terebinthifolius Raddi and all the inocula were prepared and standardized from the work culture by conventional microbiological protocols, and in conformity with the methodology proposed by the CLSI [23] [24]. We used bacterial strains obtained from the American Type Culture Collection (ATCC), where the initial cultures of Pseudomonas aeroginosa 8027, Staphylococcus aureus 6538 and 25,925 and Encherichia coli 10,536 were cultivated during $24 \mathrm{~h}$ and diluted with broth Brain Heart Infusion (BHI) culture medium for an approximate density of $7.0 \times 10^{6} \mathrm{CFU} / \mathrm{mL}$ (CFU: colony forming units).

\subsection{Microbiological Tests}

The bacterial suspensions were obtained by means of inoculation in enriched broth BHI, and then incubated at $37^{\circ} \mathrm{C}$ for $24 \mathrm{~h}$. After this period, the bacterial growth was observed by the turbidity of the samples and the inocula in agar. Of the bacterial strains about $100 \mu \mathrm{L}$ were inoculated in Mueller-Hinton (MH) agar, and using a Drigalky strap the Spread Plate technique was carried out. The filter paper discs of $5.0 \mathrm{~mm}$ diameter were positioned on the surface of the medium, and about $25 \mu \mathrm{L}$ of the crude extract was deposited after micro-dilutions in a Kline plate. The plates were incubated in a bacteriological incubator at $37^{\circ} \mathrm{C}$ and were analyzed after 24 hours. 


\section{Results and Discussion}

The internal stability of the bacterial cells depends on the interaction between a series of physiological factors, and the disturbance of this stability, may determine the bacteria's death or the inhibition of its growth [25]. To provide products, which reduce the toxicity risk and at the same time are obtained from a new natural and renewable source becomes a growing and economically viable option. The use of vegetal extracts for antibacterial activity is a consummated fact [20].

Of the bacterial strains submitted to the microbiological tests, only the Staphylococcus aureus 6538 presented inhibitions zones in agar The Schinus terebinthifolius Raddi extract in its maximum concentration produced the formation of sensitivity zones of $14.0 \mathrm{~mm}$. In agar with the dilution of $1: 2$, the sensitivity zone was of about 12.0 $\mathrm{mm}$, in the dilution 1:4 the sensitivity zone measured $10.0 \mathrm{~mm}$ and in the dilution of $1: 4$ the sensitivity zone measured $8.0 \mathrm{~mm}$. On the plates containing the dilutions 1:8 the sensitivity zone measured $8.0 \mathrm{~mm}$. On the plates containing the dilutions 1:16 and 1:32 was no formation of inhibition zones or the zone was of an insignificant size (Table 1). All the microbiological tests were performed in duplicate.

The results obtained from the $70 \%$ hydroalcoholic extract of the aroeira barks on some strains of Staphylococcus aureus 6538 showed intense inhibitory activity on the bacterial growth, from the maximum concentration (283 $\mathrm{mg} / \mathrm{mL})$ to the dilution of $1: 8$ corresponding to the minimal inhibitory concentration (MIC) of (35.3 $\mathrm{mg} / \mathrm{mL}$ ). This result corroborates with other studies in which the hydroalcoholic extracts of the Schinus terebinthifolius Raddi barks prepared with other percentages, had a similar action on the microorganisms that formed dental biofilm in dilutions of up to 1:4 [11]. Likewise other studies revealed that the 20\% aroeira bark dye presented in vitro antibacterial activity on Streptococcus mutans in dilution of up to 1:8 [4].

Besides the antibacterial activity, the hydroalcoholic extract also has an efficient action on the healing process of wounds on rats' skin [17] [21]. Schinus terebinthifolius Raddi has shown in other studies a great development potential of new products, based on plants, however little has been done to identify and characterize its chemical components which certainly is a niche that needs to be better explored [5] [18] [19] [22].

\section{Conclusions}

The Staphylococcus aureus 6538 showed to be susceptible to the hydroalcoholic extract of Schinus terebinthifolius Raddi in dilutions of up to $1: 8$, concentrations of $35.3 \mathrm{mg} / \mathrm{mL}$, being the MIC. While the strains of Pseudomonas aeruginosa 8027, Staphylococcus aureus 25,925 and Escherichia coli 10,536, showed to be resistant to the crude extract of the aroeira bark.

Hence, the obtained results show that it is of great importance to also carry out research in vivo, in order that the aroeira's extracts may be clinically used in the treatment of various bacterial conditions. The results obtained in this study show the importance of the therapeutical indications of the medicinal plants as alternative and of low cost methods, at production level, once that the hydroalcoholic extracts of aroeira showed, in vitro, important antimicrobial activity.

\section{Acknowledgements}

Sincere gratitude to the Cellular and Molecular Biology Department of the Federal University of Paraíba (MBD),

Table 1. Minimal inhibitory concentration (MIC) of the $70 \%$ hidroalcoholic extract of Schinus terebinthifolius Raddi for Staphylococcus aureus 6538.

\begin{tabular}{cc}
\hline Concentration $(\mathrm{mg} / \mathrm{mL})$ & Size of the zones $(\mathrm{mm})$ \\
$1-283.0 \mathrm{mg} / \mathrm{mL}$ & $14.0 \mathrm{~mm}$ \\
$2-141.5 \mathrm{mg} / \mathrm{mL}$ & $12.0 \mathrm{~mm}$ \\
$3-70.7 \mathrm{mg} / \mathrm{mL}$ & $10.0 \mathrm{~mm}$ \\
$4-35.3 \mathrm{mg} / \mathrm{mL}$ & $8.0 \mathrm{~mm}$ \\
$5-17.6 \mathrm{mg} / \mathrm{mL}$ & $0.0 \mathrm{~mm}$ \\
$6-8.8 \mathrm{mg} / \mathrm{mL}$ & $0.0 \mathrm{~mm}$ \\
\hline
\end{tabular}


UFPB, on behalf of the professor Dr. Hilzeth de Luna Freire Pessôa, and to the Microbiology Research Laboratory of the Integrated College of Patos, Paraíba MRL, FIP-PB.

\section{References}

[1] Duarte, M.C.T., Leme Delarmelina, C., Figueira, G.M., Sartoratto, A. and Rehder, V.L.G. (2006) Effects of Essential Oils from Medicinal Plants Used in Brazil against epec. and etec Escherechia coli. Revista Brasileira de Plantas Medicinais, 8, 139-143. http://www.readcube.com/articles/10.3390/molecules171012023

[2] Rocha, P.M.M., Rodilla, J.M., Díez, D., Elder, H., Guala, M.S., Silva, L.A. and Pombo, E.B. (2012) Synergistic Antibacterial Activity of the Essential Oil of Aguaribay (Schinus molle L.). Molecules, 17, 12023-12036. http://www.ncbi.nlm.nih.govpubmed23085653

[3] Medeiros, K.C.C., Monteiro, J.C., Diniz, M.F.F.M., Medeiros, I.A., Silva, B.A. and Piuvezam, M.R. (2007) Effect of the Activity of the Brazilian Polyherbal Formulation: Eucalyptus globulus Labill, Peltodonradicans Pohl and Schinus terebinthifolius Raddi in Inflammatory Models. Revista Brasileira de Farmacognosia, 17, 23-28. http://dx.doi.org/10.1590/S0102-695X2007000100006

[4] Soares, D.G.S., Oliveira, C.B., Leal, C., Drumond, M.R.S. and Padilha, W.W.N. (2007) Atividade Antibacteriana in Vitro da Tintura de Aroeira (Schinus terebinthifolius) na Descontaminação de Escovas Dentais Contaminadas pelo $S$. mutans. Pesquisa Brasileira de Odontopediatria Clinica Integrada, 7, 253-257. www2.ufpel.edu.br/tede/tde_busca/arquivo.php?codArquivo=1417

[5] Carvalho, M.G., Melo, A.G.N., Aragão, C.F.S., Raffin, F.N. and Moura, T.F.A.L. (2013) Schinus terebinthifolius Raddi: Chemical Composition, Biological Properties and Toxicity. Revista Brasileira de Plantas Medicinais, 15, 158-169. www.scielo.br/pdf/rbpm/v15n1/a22v15n1.pdf

[6] Fleig, M., Klein, R.M. and Reitz, R. (1989) Anacardiaceas. Flora Ilustrada Catarinense. Herbário Barbosa Rodrigues, Itajaí, 64. www.scielo.br/pdf/abb/v25n2/a03v25n2.pdf

[7] Universidade de São Paulo. Biblioteca virtual do estudante brasileiro (2013) Aroeira. http://www.bibvirt.futuro.usp.br/acervo/paradidat/frutas/aroeira/aroeira

[8] Coutinho, I.H.I.L.S., Torres, O.J.M., Matias, J.E.F., Coelho Jr., J.C.U., H.J.S., Agulham, M.A., Bachle, E., Camargo, P.A.M., Pimentel, S.K. and Freitas, A.C.T. (2005) Efeito do extrato hidroalcoólico da aroeira (Schinus terebinthifolius Raddi) na cicatriação de anastomoses colônicas. Estudo experimental em ratos. Acta Cirurgica Brasileira, 21.

[9] Bornhausen, R. (2013) Ervas do sítio. http://www.ervasdositio.com.br/enciclopedia/enciclopedia.asp

[10] Leite, S.R.R.F., Amorim, M.M.R., Sereno, P.F.B., Leite, T.N.F., Ferreira, J.A.C. and Ximenes, R.A.A. (2011) Randomized Clinical Trial Comparing the Efficacy of the Vaginal Use of Metronidazole with a Brazilian Pepper Tree (Schinus) Extract for the Treatment of Bacterial Vaginosis. Brazilian Journal of Medical and Biological Research, 44, 245-252. http://www.ncbi.nlm.nih.govpubmed21243318

[11] Alves, L.A. (2011) Ação antifungicida da tintura de Schinus terebinthiglolius Raddi (Aroeira) sobre Candida albicans. Trabalho de Conclusão de Curso (Bacharelado em Odontologia), Universidade Federal da Paraíba, João Pessoa.

[12] Degaspari, C.H., Waszczynskyj, N. and Prado, M.R.M. (2005) Atividade antimicrobiana de Schinus terebinthifolius Raddi. Revista Ciências e Agrotecnologia, 29, 617-622. www2.fcfar.unesp.br/.../CienciasFarmaceuticas/ademir-salvi-junior---do.pdf

[13] Silva, M.A.V. (2007) Avaliação fisiológica da aroeira (Schinus terebinthiglolius Raddi) sob déficit hídrico com vista para o reflorestamento. Recife, 2007. Dissertação (Mestrado em Ciências Florestais), Universidade Federal Rural do Pernambuco, Recife.

[14] Santos, M.R.A., Lima, R.A., Silva, A.G., Lima, D.K.S., Scllet, L.A.P., Teixeira, C.A.D. and Facundo, V.A. (2013) Composição química e atividade inseticida do óleo essencial de Schinus terebinthifolius Raddi (Anacardiaceae) sobre a broca-do-café (Hypothenemeus hampei) Ferrari. Revista Brasileira Plantas Medicinais, 15, 757-762.

[15] Fernades, P. (2006) Antibacterial Discovery and Development-The Failure of Success? Nature Biotechnology, 24, 1497-1503. http://www.ncbi.nlm.nih.gov/pmc/articles/PMC2189988 http://dx.doi.org/10.1038/nbt1206-1497

[16] Martinez, J.L. (2009) The Role of Natural Environments in the Evolution of Resistance Traits in Pathogenic Bacteria. Proceedings of the Royal Society B: Biological Sciences, 276, 2521-2530. http://dx.doi.org/10.1098/rspb.2009.0320 http://www.hindawi.com/journals/bmri/2012/834598/

[17] Smith, E., Williamson, M., Zloh, M. and Gibbons, S. (2005) Isopimaric Acid from Pinus nigra Shows Activity against Multidrug-Resistant and EMRSA Strains of Staphylococcus aureus. Phytotherapy Research, 19, 538-542. http://dx.doi.org/10.1002/ptr.1711

[18] Pitt, T.L. and Simpson, A.J.H. (2006) Principles and Practice of Clinical Bacteriology. 2nd Edition. 
[19] Fuentefria, D.B., Ferreira, A.E., Gräf, T. and Corção, G. (2008) Pseudomonas aeruginosa: Disseminação de resistência antimicrobiana em efluente hospitalar e água superficial. Revista da Sociedade Brasileira de Medicina Tropical, 41. http://www.lume.ufrgs.br/bitstream/handle/10183/18618/000731071.pdf

[20] Demain, A.L. and Sanchez, S. (2009) Microbial Drug Discovery: 80 Years of Progress. The Journal of Antibiotics, 62, 5-16. http://www.nature.com/ja/journal/v62/n1/full/ja200816a.html

[21] Corrêia, C., Ming, L.C. and Sheffer, M.C. (1994) Cultivo de Plantas Medicinais, Condimentares e Aromáticas. 2nd Edition, FUNEP, Jaboticabal, 162 p. http://www.cpap.embrapa.br/publicacoes/online/FOL104.pdf

[22] Steenbock, W. (1999) Cultivo de Plantas Medicinais. Prefeitura Municipal de Guarapuava, Guarapuava.

[23] Alves, E.G., Vinholis, A.H.C., Casemiro, L.A., Furtado, N.A.J.C., Silva, M.L.A.E., Cunha, W.R. and Martins, C.H.G. (2008) Estudo comparativo de técnicas de screening para avaliação da actividade antibacteriana de extratos brutos de espécies vegetais e de substâncias puras. Química Nova, 31, 1224-1229.

[24] Clinical and Laboratory Standards Institute (CLSI) Performance Standards for Antimicrobial Disc Susceptibility Test, Aproved Standard. 10th Edition, CLSI Document M02-A10, CLSI, Wayne.

[25] Nolte, W.A. (1982) Oral Microbiology. Mosby, London, 3-37. http://www.dentaria.com/artigos/ver/?art=38 
Scientific Research Publishing (SCIRP) is one of the largest Open Access journal publishers. It is currently publishing more than 200 open access, online, peer-reviewed journals covering a wide range of academic disciplines. SCIRP serves the worldwide academic communities and contributes to the progress and application of science with its publication.

Other selected journals from SCIRP are listed as below. Submit your manuscript to us via either submit@scirp.org or Online Submission Portal.
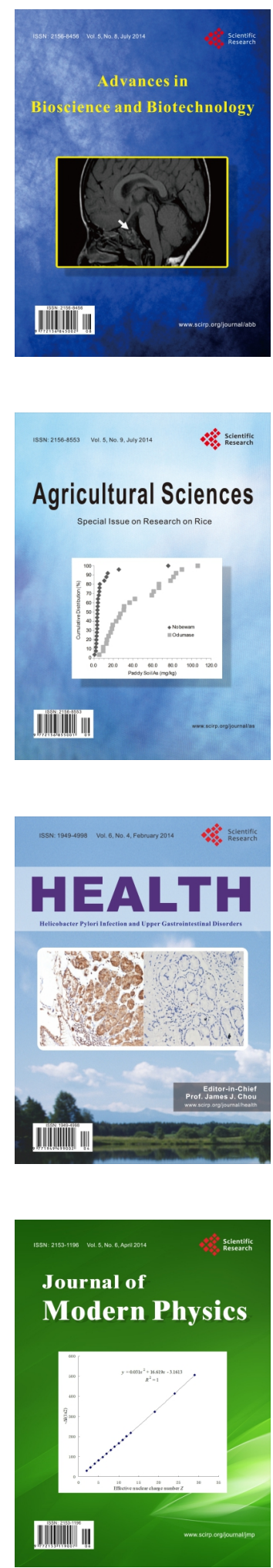
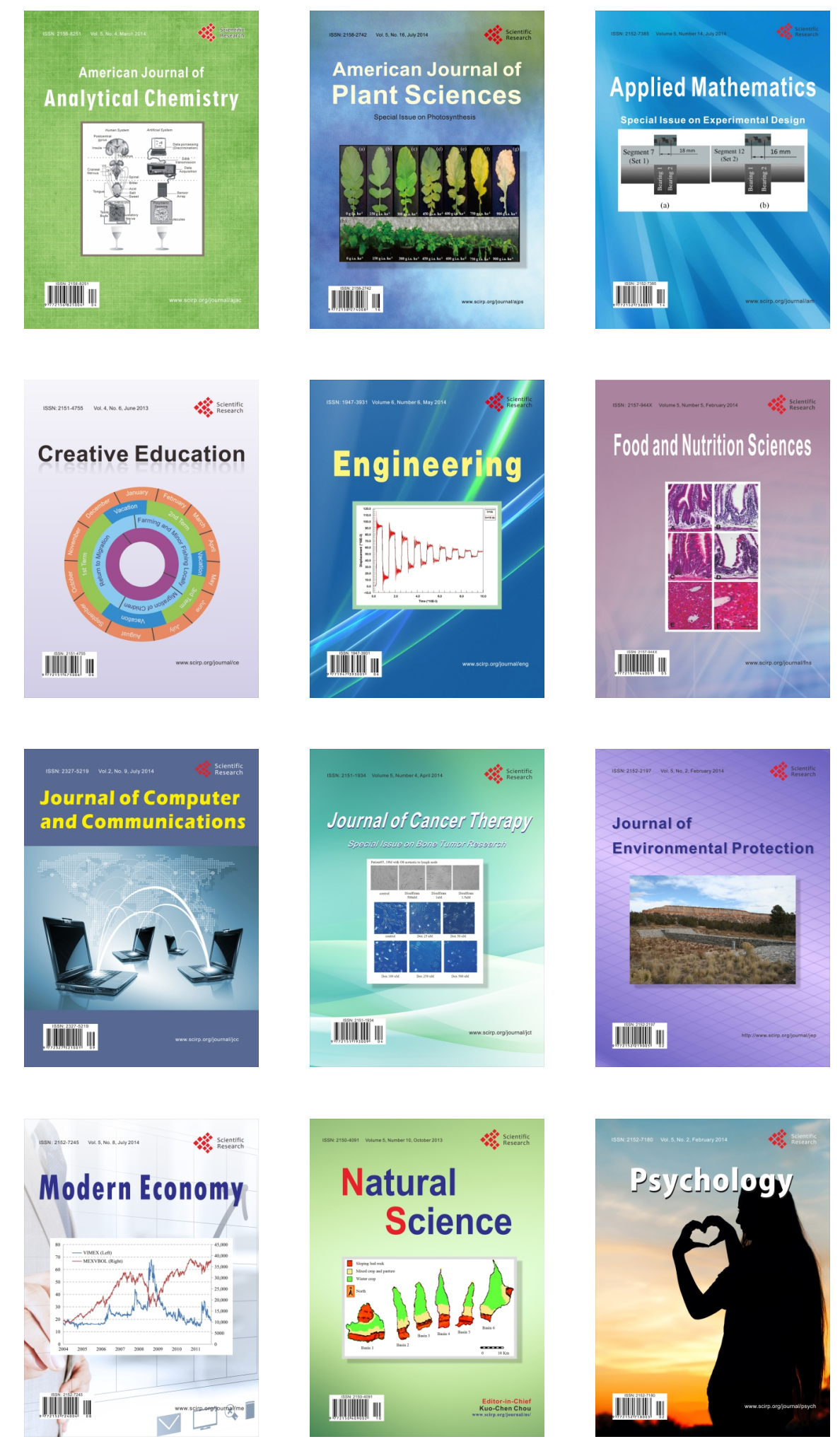